\title{
Women in the Workforce: Still Unequal after all these Years?
}

Amanda Reilly and Annick Masselot

In 1893, women in New Zealand were the first in the world to get the vote and in more recent times women have had a run as Prime Minister, Opposition Leader, Chief Justice and Governor General. Even the Queen is a woman. The country's most famous pop singer, best known opera star, most famous short story writer, greatest novelist and most consistent world champion athlete are all women. They're not allowed in the All Blacks as yet, but don't be fooled. It's just a matter of time...

\section{Introduction}

The John Clarke quote above paints a picture of New Zealand women inexorably striding forward in terms of gender equality. It is true that women in New Zealand have a low gender pay gap at 'only' 11.8 per cent in $2015 .^{2}$ This is consistently one of the lowest in the world when comparing full-time workers. ${ }^{3} \mathrm{New}$ Zealand women's employment rate is one of the highest in the OECD (Organisation for

1 John Clarke “New Zealand: A User's Guide” (2014) Briefing Papers <http://briefingpapers. co.nz/new-zealand-a-users-guide/>. Clarke was a well-known social commentator and comedian.

2 Ministry for Women "Empirical evidence of the gender pay gap in New Zealand" (1 March 2017) <http://women.govt.nz/our-work/utilising-womens-skills/income/gender-pay-gap>; Statistics New Zealand "Measuring the gender pay gap" (19 January 2016) <http://www. stats.govt.nz/browse_for_stats/income-and-work/Income/gender-pay-gap.aspx $>$.

3 Ministry for Women "New Zealand Women" <http://women.govt.nz/new-zealandwomen\#sthash.2o5JqUey.dpuf>. 
Economic Co-operation and Development $)^{4}$ at 64.7 per cent in $2015 .{ }^{5}$ New Zealand also frequently tops various international gender equality indexes and reports. ${ }^{6}$ New Zealand women have made considerable progress in terms of equality. There are more women working in the labour market and in professions now than 40 years ago, which represents a formidable structural transformation. ${ }^{7}$ Nevertheless, female labour force participation here is still lower than their male counterparts (12 per cent difference between the sexes in 2011). ${ }^{8}$ Worse yet, there is backsliding: the number of women in senior positions ${ }^{9}$ is declining and the gender pay gap is increasing. ${ }^{10}$ While workforce transformation has been dramatic for New Zealand women, there is still some way to go to reach gender equality here.

Tounderstand how far we have come and to understand the drivers of workplace transformation for women, we need to understand where we started from. This chapter draws on articles published over 40 years in the New Zealand Journal of Employment Relations (NZJER) (formerly the New Zealand Journal of Industrial Relations (NZJIR)) to summarise progress and setbacks over the decades. It then

4 Reports on the rate of women in the NZ labour force varies from 62.5 per cent in the Household Labour Force Survey to 72 per cent in the World Economic Forum Report. Department of Labour Labour Force Participation in New Zealand: Recent Trends, Future Scenarios and the Impact on Economic Growth (Department of Labour, Wellington, 2009); Department of Labour and World Economic Forum "Global Gender Gap Report 2014” (January 2014) <http://www3.weforum.org/docs/GGGR14/GGGR_CompleteReport_2014.pdf >.

5 Ministry for Women "New Zealand Women" (March 2015) <http://women.govt.nz/newzealand-women\#sthash.2o5JqUey.dpuf>.

6 World Economic Forum "Global Gender Gap Report 2013” (2013) <http://www3.weforum. org/docs/WEF_GenderGap_Report_2013.pdf>.

7 Since 1986 the female labour force has increased by more than 50 per cent. In 2016 women's labour force participation was 64.5 per cent, above the OECD average. Ministry for Women "Labour Force Participation" <http://women.govt.nz/work-skills/paid-and-unpaid-work/ labour-force-participation>.

8 Families Commission Families and Whanau Status Report 2013 (Families Commission, Wellington, 2013) at 62.

9 Ministry for Women "Women in Leadership" < http://women.govt.nz/our-work/womenleadership>. Only 14.75 per cent of the NZSX 100 directorships in 2012 were women and this number decreased with only 12 per cent of female directors disclosed by 109 NZSX companies in 2013. Judy McGregor "New Zealand Census of Women's Participation 2012" (2012) <www.hrc.co.nz>; and New Zealand Stock Exchange "Gender Diversity Annual Statistics Memorandum" <www.nzx.com>. For a general oversight of the situation of female board members on large listed private companies in New Zealand, see Annick Masselot and Timothy Brand "Diversity, quotas and compromise in the boardroom: Can New Zealand adopt a legislation to tackle gender imbalance in economic decision making?” (2015) 26 NZULR 23.

10 Since the late 1990s the gender pay gap has been steadily reducing from 16.3 per cent in 1998 to 9.1 per cent in 2012, but since then the gap is increasing. In 2016, the gender pay gap was 12 per cent. Ministry for Women “Gender Pay Gap” <http://women.govt.nz/work-skills/ income/gender-pay-gap>. 
identifies the continuities with the past as well as areas of progress to determine where New Zealand women are currently at and to pinpoint changes that will need to be made if there is to be further progress.

\section{The Third National Government (1975-1984)}

Certainly in comparison to what had gone before, the 1970s heralded a progressive period for women's employment. Female labour market participation was at 32.5 per cent in 1976 compared to 20 per cent in $1926 .{ }^{11}$ The 1970 s witnessed the adoption of some serious legislative support for women's participation in the workforce. In the 1950s the Public Service Commission set different levels for salary progression for men and women; the Government Service Equal Pay Act 1960 put an end to this practice and the Equal Pay Act 1972 extended the principle of equal pay to the private sector. ${ }^{12}$ The Human Rights Commission Act $1977^{13}$ also provided that it was illegal to discriminate on the grounds of sex in terms of employment, conditions of work, fringe benefits and opportunities for training, promotion, and transfers to people with the same or substantially similar qualifications. ${ }^{14}$ On the international scene, New Zealand ratified the United Nations Convention on the Elimination of all Forms of Discrimination against Women (CEDAW) in 1979.

Despite these normative improvements, the legal framework reflected a social setting which would be unimaginable nowadays..$^{15}$ For instance, the Factories Amendment Act 1972 set limits on the hours that women could work at night in factories, with no comparable restriction for men, effectively depriving women of the opportunity to earn overtime. There were restrictions on the weights women were permitted to lift and Sharp notes the practice which then existed of some firms giving women workers one half day off work each month to go shopping. ${ }^{16}$ Women were also treated in law as dependents: under Regulation 56(2) of the Public Service Regulations 1964, a government department would meet transfer expenses for an employee and his family, but transfer expenses for married women employees would have to be referred to the State Services Commission. ${ }^{17}$ While these restrictions are now gone, some of the most structural issues have remained the same. For example, then as now, there is a gender pay gap.

11 Audrey Sharp "Towards equal employment opportunity for women” (1978) 3 NZJIR 121.

12 Equal Pay Act 1972, s 2A.

13 Now repealed under the Human Rights Act 1993.

14 Human Rights Commission Act 1977, s 15(1)(b), also extending to cases of dismissal, s 15(1) (c).

15 Above $\mathrm{n} 11$ at 125.

16 At 125.

17 At 126. Similarly, under the Education (Staff and Salaries) Regulation, the education manual allowed for the removal expenses for a married woman only if her husband was shown to be totally dependent on her. 


\section{Gender Pay Gap}

According to Hyman, in May 1980 women's gross weekly earnings were 62.3 per cent of those of a man. ${ }^{18}$ Hyman notes some narrowing of the differences between men and women's earnings between 1973 and 1977 following the period of implementation of the equal pay legislation. The Equal Pay Act certainly helped reduce gender pay discrimination through its elimination of separate male and female rates in awards, agreements, scales and other collective agreements. ${ }^{19}$

\section{Female Dominated Occupations and Job Segregation}

Then, as now, women clustered in female dominated occupations. Hyman observes that occupational segregation between the sexes was extreme and diminished only very slowly. ${ }^{20}$ Women formed just over one third of the labour force, yet over half of all women workers were engaged in occupations which were over 70 per cent female or more. ${ }^{21}$

In the 1970s New Zealand women were not represented in all job areas but were concentrated mainly in three industrial groups: (1) community, social and personal health services (that is, teaching and health); (2) manufacturing; and (3) wholesale and retail, restaurants and hotels.

\section{Women and Unions}

As highlighted by Butterworth, the particular industries women were clustered in were characterised by widely dispersed small units, subject to cyclical and seasonal fluctuations and shifts. Butterworth notes this posed particular problems for union organisation. ${ }^{22}$ This lack of female trade union involvement and activism was also echoed by Paterson, ${ }^{23}$ who applauds researchers who connect women's low participation in unions with their disadvantaged marginal and segregated labour market status. Indeed, the absence and inaction of unions with regards to women workers left women vulnerable to the grossest

18 Prue Hyman "Women and pay" (1978) 6 NZJIR 79 at 80. Over the years Prue Hyman has been a strong advocate for recognition of the need for further action to address the status of women in New Zealand and a consistent presence in the pages of the New Zealand Journal of Employment Relations. Her most recent book, Hopes Dashed? The Economics of Gender Inequality (Bridget Williams Books, Wellington, 2017), continues this work.

19 Prue Hyman "Equal pay for women after the Employment Contracts Act: Legislation and practice - The emperor with no clothes?” (1993) 18 NZJIR 44 at 47.

20 Prue Hyman "Review Article: Women and Pay" (1981) 6 NZJIR 79 at 83.

21 Above $\mathrm{n} 11$ at 122.

22 Ruth Butterworth "Women in the workforce" (1978) 3 NZJIR 11 at 11.

23 Karen Paterson "Review of - Geare Alan, Joyce Herd, and John Howells, Women in trade unions: A case study of participation in New Zealand'. Victoria University of Wellington, Industrial Relations Centre, 1979” (1979) 4 NZJIR 43. 
exploitation and the "plight and plaints of women workers have too often been ignored by male dominated unions". ${ }^{24}$

\section{The Distinctive Position of Mäori and Pasifika Women}

Butterworth also comments on the particular disadvantage of Māori and Pasifika women who were often hampered by family responsibility, needing a wage but limited in hours and ability to travel compounded by other challenges including language and lack of contact with formal agencies. ${ }^{25}$ Revell and Brosnan further comment in a later article that there are substantially different participation rates for different ethnic groups. ${ }^{26}$ New Zealand's non-Māori female workforce has been increasing almost continuously since $1891^{27}$ while Māori female participation has been lower than non-Māori female participation at every census since comparable data first became available.

\section{Lack of Work-Family Reconciliation Mechanisms}

Finally, the 1970s were characterised by a lack of work-family reconciliation mechanisms. Sharp comments on a reluctance on the part of employers "to concede variations in working hours" 28 and also explains that 86 per cent of awards in 1976 made no provision for maternity leave at all. However, in 1980, the Maternity Leave and Employment Protection Act 1981 was introduced, which allowed women to take unpaid maternity leave for up to 26 weeks and prohibited dismissal due to pregnancy or maternity leave. The protection applied under two conditions. First, women had to have been employed by the same employer for the immediately preceding 18 months for at least 15 hours a week. Second, their position would be presumed to be kept open unless the employer proved that it could not be kept open.

Whilst this new Act was definitely a step in the right direction, it was only a small step. The legislation was subject to sharp criticism by Szakats ${ }^{29}$ who noted the complete lack of pay during the leave - either in the form of a welfare payment or the continuation of wages - which made it stingy compared to the relative generosity of overseas provisions. In comparing the British and German systems, he concluded that this legislation offered the least protection. ${ }^{30} \mathrm{He}$ also

24 Above $\mathrm{n} 22$, at 12 .

25 Above $\mathrm{n} 22$, at 14 .

26 Phillipa Revell and Peter Brosnan "New Zealand labour force participation: The ninety years to $1981 ”$ (1986) 11 NZJIR 88.

27 At 79.

28 Above $\mathrm{n} 11$, at 121.

29 Alexander Szakats "Maternity leave legislation: The timidity of the New Zealand approach" (1981) 6 NZJIR 11 at 19.

30 At 18. 
criticised the lack of paternity leave provision for fathers who might have to stay at home to look after older children. Moreover, he argued that the employment protection provision "amounts to a mere possibility - not a probability let alone a firm right to be re-employed after 26 weeks if the job or a similar job is available". ${ }^{31}$ He finally concluded that the protection offered was misleading: "the statute appears to grant a protection which might prove to be illusory, like the fairy tale gift which the hero was commanded to give, and not to give to the king. He solves this impossible demand by presenting a bird which immediately flew away". ${ }^{32}$

In the final years of the Muldoon government, at least two other legislative developments are noteworthy: (1) the Minimum Wage Act 1982 entitled women over 20 to the same minimum wage as men; and (2) the International Labour Organisation (ILO) Convention on Equal Remuneration was ratified in 1983.

\section{The Fourth Labour Government (1984-1990)}

In 1984, a Labour government took power and the years of 'Rogernomics' began. ${ }^{33}$ Although women suffered alongside men due to the effects of deregulation, legislatively a number of measures aimed at furthering the position of women in the workplace were put in place. A feature of the 1980s was that the trade union movement - historically male dominated - became more responsive to women's concerns as women achieved positions of power within the unions and with a growth of women unionists representing occupational groups with large female memberships. ${ }^{34}$ Politically, as well, women organised politically and their "assaults on the citadels of political power" produced various law changes. ${ }^{35}$

The Ministry of Women's Affairs was established and recognised as a separate department in 1984. The Parental Leave and Employment Act 1987 strengthened rights of mothers to return to their employment at the end of their leave. The 1987 Act extended the period of unpaid maternity leave from 26 to 52 weeks and extended the protection to both parents. The Act also introduced two

31 At 19.

32 At 19.

33 The term Rogernomics - a portmanteau of Roger and economics - was coined by journalists at the New Zealand Listener by analogy with Reaganomics to describe the economic policies followed by Roger Douglas after his appointment in 1984 as Minister of Finance in the Fourth Labour Government of New Zealand. Such politics were characterised by market-led restructuring and deregulation.

34 Linda Hill and Rosemary Du Plessis "Tracing the similarities, identifying the differences: Women and the Employment Contracts Act” (1993) 18 NZJIR 31 at 43; Margaret Wilson "Contractualism and the Employment Contracts Act 1991: Can they deliver equality for women?” (1994) 19 NZJIR 256 at 274.

At 274 . 
weeks' unpaid leave for fathers. ${ }^{36}$ The eligibility requirements were reduced to 12 months' service of 10 hours or more per week. ${ }^{37}$ Sexual harassment provisions were introduced in 1987 in the Labour Relations Act. The State Sector Act adopted in 1988 set requirements for policies on equal employment opportunities in the state sector. Public Service and the public health and public education sectors were required to be good employers and to create Equal Employment Opportunities (EEO) plans and practices to deal with discrimination.

Pay equity - that is, the issue of whether men and women get the same or a similar wage for doing a comparable job - became a focus of concern in 1986. A group of working and union women established the 'Coalition for Equal Value Equal Pay'. As discussed by Hyman ${ }^{38}$ this grew out of a dissatisfaction with the Equal Pay Act 1972, which apparently failed to clearly incorporate the principle of equal pay for work of equal value. Presciently, she notes that "the Act appears to extend well beyond equal pay for identical work to allow comparisons on the basis of skills, effort, responsibility and conditions." ${ }^{39}$ There was "considerable doubt that it was ever applied in this way and the Arbitration court judgment in the 1986 Clerical Workers Case means that for all practical purposes this is now impossible". ${ }^{40}$

The Coalition for Equal Value Equal Pay produced a report, 'Towards Employment Equity', which recommended new legislation covering equal opportunity and equal pay for work of equal value. The recommendations hinged on comparisons of work between female and male occupational classes. The Employment Equity Act 1990, was the culmination of this concerted activism. In 1989, the Employment Equity Bill had its first reading and was passed by Labour in 1990. It provided a way in which national award negotiations "could address systematic gender inequality in access to earnings using pay equity assessments provided by the Employment Equity Commission". ${ }^{4}$

36 Pheroze Jagose "Babies and bosses: An examination of section 41 of the Parental Leave and Employment Protection Act 1987” (1994) 19 NZJIR 131 at 150.

37 Paul Callister and Judith Galtry "Paid parental leave in New Zealand: A short history and future policy options" (2006) 2 Policy Quarterly, 38 at 46.

38 Prue Hyman "Equal pay for work of equal value - Job evaluation issues" (1988) 13 NZJIR 237 at 237.

39 Much later, in Bartlett $\nu$ TerraNova in 2015, the New Zealand Courts accepted that the Equal Pay Act could be interpreted to mean that equal pay for work of equal value did not simply mean the same pay for the same work. However, prior to this decision, the Act had been effectively neutered in 1986 when the Clerical Workers Union took a case to the Arbitration Court seeking a ruling that employers should be directed to negotiate a claim for equal pay for work of equal value and the Court dismissed the case.

40 Hyman above n 38 at 237 referring to New Zealand Clerical Administrative etc IUOW $\nu$ Farmers Trading Co Ltd [1986] ACJ 203 (AC).

41 Linda Hill and Rosemary Du Plessis "Tracing the similarities, identifying the differences: Women and the Employment Contracts Act” (1993) 18 NZJIR 31 at 33. 


\section{Fourth National Government (1990-1999)}

A change of government in 1990 heralded the era of the Employment Contracts Act, which was passed in 1991. Characterised by an ideology that was anti-union and anti-market intervention, it moved New Zealand's labour relations system away from the historical tradition of conciliation and arbitrations to settle wages and conditions of employment, to a system centred on the negotiation of individual and collective contracts. The Employment Equity Act 1990 was antithetical to this and was deeply embedded in the previous system of wage fixing. It was repealed after only a month and thus, as commented by Margaret Wilson, who was a key architect of the legislation, it "must have had one of the shortest legislative lives on record". ${ }^{42}$

It would not be true to say that the then National Government evinced no concern with regards to the disadvantaged position of women in the workplace. However, the National Working Party on Equity in Employment considered that "progress towards an equal employment opportunities environment will be most effectively achieved where employers are closely involved in the voluntary promotion of progressive EEO management practices". ${ }^{43}$ Equal employment opportunities were defined as being where "all employment and promotion decisions are made on the basis of merit". ${ }^{44}$ An Equal Employment Opportunities approach is not concerned with measuring equality outcomes, but rather with inputs in the sense of the introduction of bureaucratic measures aimed at reducing indirect barriers by developing and implementing policies and programmes which promote objective criteria and offer management training for women. Accordingly, in 1992 the EEO Trust was established to promote EEO programmes and practices in private sector workplaces. Described by Hyman as "small and toothless, but acceptable [and] at least working for positive change", the EEO (now known as Diversity Works) has largely and to this day focused on the business case for diversity. ${ }^{45}$

Another change which could be seen as seeking to protect women and other groups from discrimination was the adoption of the Human Rights Act 1993, which replaced the Human Rights Commission Act 1977. The protection against discrimination provided by this legislation mirrored that of the Employment Contracts Act providing alternative routes for the aggrieved employee: ${ }^{46}$

42 Margaret Wilson "Contractualism and the Employment Contracts Act 1991: Can they deliver equality for women?” (1994) 19 NZJIR 256 at 266.

43 At 270.

44 Rose Ryan "Collection: Women at work - Issues for the 1990s" (1993) 18 NZJIR 1.

45 Prue Hyman "Equal pay for women after the Employment Contracts Act: Legislation and practice - The emperor with no clothes?” (1993) 18 NZJIR 44 at 55.

46 Peter Kiely "Discrimination and human rights: An overview of remedies" (1993) 18 NZJIR 375. 
There is no doubt that the passing of the Human Rights Act has indicated a new commitment to the prevention of discrimination in New Zealand. The Act sends a clear message to both employers and the Courts that discrimination in the workplace is unacceptable and will be punished. The raising of the maximum amount of damages from $\$ 2000$ to $\$ 200000$ for humiliation, loss of dignity and injury feelings certainly gives the Courts the power to be more severe in their orders.

The Conciliation system had its faults and it is questionable how much it ever would have furthered equality even if the Employment Equity Act had managed to be fully implemented. ${ }^{47}$ Proponents of the Employment Contracts Act argued that it would be good for women: ${ }^{48}$

Some advocates of the Employment Contracts Act argued that that it would strip away the institutional forms which, in a variety of ways, perpetuated women's unequal access to earnings. It was presented as offering women just what they wanted "flexibility" and the "freedom" to determine their own wages and conditions of employment in direct negotiations with their employers.

However, there were many that expressed doubt about the Employment Contracts Act, pointing to the weak bargaining position of women ${ }^{49}$ and the inequality that employers and employees bring to negotiations. ${ }^{50}$ That inequality was most pronounced in low-wage jobs. Those who predicted the Employment Contracts Act did not have any advantages for women were soon proven correct ${ }^{51}$ as the pay gap between men and women started to stagnate and widen. In 1994, the ILO Application of Standards Committee heard evidence regarding the Convention 100 on Equal Remuneration that after decades of slow but steady progress, the introduction of the ECA had resulted in a steady widening of the gap between men's and women's wages as well as effectively rendering inoperative the Equal Pay legislation. ${ }^{52}$

47 Rosemary Du Plessis Novitz, and Nabila Jabert "Pay equity, the 'free' market and state intervention" (1990) 15 NZJIR 251 at 256; see also Prue Hyman "Equal pay for women after the Employment Contracts Act: Legislation and practice - The emperor with no clothes?” (1993) 18 NZJIR 44 at 46.

48 Linda Hill and Rosemary Du Plessis "Tracing the similarities, Identifying the Differences: Women and the Employment Contracts Act" (1993) 18 NZJIR 31 at 33.

49 Janet Sayers "Women, the Employment Contracts Act and bargaining: a discussion paper" (1991) 16 NZJIR 159.

50 Margaret Wilson "Contractualism and the Employment Contracts Act 1991. Can they deliver equality for women?” (1994) 19 NZJIR 256.

51 Suzanne Hammond and Raymond Harbridge "The impact of the Employment Contract Act on women at work" (1993) 18 NZJIR 15; Suzanne Hammond and Raymond Harbridge "Women and enterprise bargaining: The New Zealand experience of labour market deregulation" (1995) 20 NZJIR 359; and Raymond Harbridge and Maryan Street "Labour market adjustment and women in the service industry: A survey” (1995) 20 NZJIR 1.

52 Robert Wilson "The decade of non-compliance: The NZ government record of non-compliance 


\section{The Fifth Labour Government (1999-2008)}

In 2000 a Labour-led government took power again and the Employment Contracts Act was replaced by the Employment Relations Act. The Clark government demonstrated more commitment to furthering equality for women in the workplace than previous governments. There was progress on a number of fronts and particularly in relation to the issue of work-life balance. Such steps were underpinned by the idea of social development, social inclusion and social investment, but they were also realised as a way to increase and strengthen female labour force participation..$^{53}$

\section{Work-Family Balance Mechanisms}

Three pieces of employment legislation were adopted as the back bones of the New Zealand work-family balance architecture. First, the Parental Leave and Employment Protection Act 1987 was amended in $2002^{54}$ to introduce for the first time in New Zealand the right to paid parental leave. (Qualifying) parents, ${ }^{55}$ employed in minimum employment, could take up to 12 weeks of governmentfunded paid parental leave as well as up to 52 weeks of job-protected unpaid parental leave. The leave could be transferred to the qualifying father but was conditional upon the mother qualifying first. In December 2004, the paid parental leave was increased to 14 weeks and the eligibility criteria were extended to employees who had six months or more continuous service with the same employer. In July 2006, the entitlement to paid parental leave was extended to the self-employed.

Although the adoption of the legislation introducing paid parental leave has been positively evaluated by families who have been entitled to the payment, ${ }^{56}$ the

with international labour standards, 1990-1998” (2000) 25 NZJIR 84.

53 See, in particular, "Prime Minister's Opening Statement to Parliament" (2004) <www. beehive.govt.nz/Print/PrintDocument.aspx?DocumentID=18877> and (2005) <www. beehive.govt.nz/Print/PrintDocument.aspx?DocumentID=22087 >.

54 Parental Leave and Employment Protection Amendments Acts 2002.

55 In order to qualify, parents must have continuously been employed or self-employed for an average of 10 hours a week and no less than one hour in every week or 40 hours in every month, for the twelve months immediately before the expected date of birth or adoption: Parental Leave and Employment Protection Amendments Acts 2002, s 7. The entitlement varies according to the length of the continuous period of employment. Employees who meet the minimum hour test but only over six months of continuous period of employment qualify for the 14 weeks paid leave but not for the extended unpaid leave. The Act also covers selfemployed individuals who have worked for an average of 10 hours a week over 12 months immediately before the birth or the adoption. Similar restrictions are imposed on selfemployed persons who meet the minimum hour test but for only six months of continuous self-employment.

56 Katherine Forbes "Paid parental leave under (new) labour" (2009) 34 SPJNZ 12. 
Act fails to respond to work-family conflict for many families. ${ }^{57}$ The qualifying requirement meant that a large number of women - especially those in precarious employment - have not been able to benefit from the legislation. ${ }^{58}$ Moreover, paid parental leave has always been limited in New Zealand and capped to 50 per cent of the average weekly earnings, lower than the minimum wage, inferring that production is more valued than reproduction. ${ }^{59}$ In addition, the "raison d'etre of the paid parental leave ... has been to contribute to economic growth rather than the wellbeing of families". ${ }^{60}$

Second, the Employment Relations (Breaks, Infant Feeding, and Other Matters) Amendment Act 2008 created a right for employees who are breastfeeding and wish to breastfeed to request adequate (but unpaid) breaks and appropriate facilities. The Act was introduced to reflect New Zealand's international obligations under the United Nations Committee on the Elimination of All Forms of Discrimination against Women (CEDAW 2003). To help employers understand their obligations, the Minister of Labour must under the Act publish a Code of Employment Practice. Although the code of practice should aim to provide useful guidance on the range of factors an employer can consider when negotiating a breastfeeding arrangement and gives practical ideas on the factors to consider, such as health and safety, facilities, resources and space for breastfeeding employees, the first advice given is that "there is no absolute obligation on employers to provide breaks and/or facilities". ${ }^{11}$ This gives a frivolous tone to the Act, which limits the employers' obligation to reasonable and practical circumstances relating to the employer's operational environment and resources. The Act, far from being concerned with infants' wellbeing or gender equity, is considered as an instrument to enhance the functioning of the labour market. ${ }^{62}$

Finally, the main tool for the work-family balance mechanism in this period was developed though the Employment Relations (Flexible Working Arrangements) Amendments Act 2007, which created a statutory right for employees who have care responsibilities for any person to request a variation in their time and place

57 Families Commission The Kiwi Nest: Sixty Years of Change in New Zealand Families (Families Commission, Wellington, 2008).

58 Sarah Crichton Work Patterns after Paid Parental Leave (Department of Labour and Statistics, New Zealand, 2008).

59 Annick Masselot "The right and reality of flexible working arrangements in New Zealand" in Grace James and Nicole Busby (eds) Families, Care-Giving and Paid Work (Edward Elgar, Cheltenham, 2011) at 69-85.

60 Katherine Forbes (2009) "Paid Parental Leave under (New) Labour" 34 Social Policy Journal of New Zealand 12, at 20.

61 Kate Wilkinson "Information for mothers who are returning to work" (2010) avaiable at <https://www.employment.govt.nz/hours-and-wages/breaks/breastfeeding-at-work/>

62 Paul Callister and Judith Galtry "'Baby bonus' or paid parental leave: Which one is better?” (2009) 34 SPJNZ 1. 
of work. The right to request operated under three conditions of application: (1) the request had to be linked to the existence of a care commitment for the employee; (2) the employee had to have at least six months continuous service with the same employer; and (3) the request could only be made once every 12 months by the same employee. The request process was relatively heavy and complex. It had to be made in writing, explain what variations were required and how the said variations would enable the provision of better care for the dependent. Employers were obligated to consider the request seriously and in a timely fashion (within three months of receipt of the request) but could refuse on the grounds that the variations were not compatible with the business operation.

The Act provided a grievance mechanism, a right of appeal and a penalty of up to $\$ 2,000$ in compensation to the aggrieved employee. However the difficulty of accessing justice and the relatively low level of compensation has left the Act without the necessary teeth to truly enact change. The right to request was, in the main, not actually used formally. Most employees have the right to ask for changes in their terms and conditions of employment. The right to request only represented a symbolic yet powerful acknowledgment of employees' care commitment. ${ }^{63}$

Overall, this period shows a great deal of activity related to work-life balance and some significant policy developments. There is no doubt that those laws contributed to transforming the work place as well as supporting women's ability to participate in the labour market. However, Ravenswood rightly pointed out that these work-family balance mechanisms were still primarily motivated by the business case within a liberal paradigm and they did not go far enough in recognising the value of care work. ${ }^{64}$ Indeed, the New Zealand work-life balance policy, as developed in the 2000-2009 period, lags behind many post-industrial countries. ${ }^{65}$

\section{Access to Childcare}

Moreover, work-life balance policy cannot be considered in isolation from the strategy on care and specifically on childcare. Although childcare is not placed within the realm of employment law, the impact of the organisation of care on the labour market participation of women in particular is significant.${ }^{66}$ Childcare

63 Annick Masselot "Gender implications of the right to request flexible working arrangements: Raising pigs and children in New Zealand” (2015) 39 NZJER 59.

64 Katherine Ravenswood "The role of the State in family-friendly policy: An analysis of Labourled government policy” (2008) 33 NZJER 34.

65 Annick Masselot "The right and reality of flexible working arrangements in New Zealand" (2011); and Katherine Forbes "Paid parental leave under (new) labour" (2009) 34 SPJNZ 12.

66 OECD Teachers Matter: Attracting, Developing and Retaining Effective Teachers (OECD, Paris, 2005). 
has been a private issue for a long time with women doing the bulk of the work for free but at a cost. In the 1980s and 1990s, the substantial increase of female workforce participation precipitated the debate over childcare in many developed countries. Early childcare in New Zealand had been skewed almost exclusively towards private organisations. This has resulted in a booming private sector with high prices and large inequality of access. In 2004, the Working for Families scheme was introduced to provide incentives for people to work, especially solo parents. The weighing up of care versus work dilemma faced by many women meant that the government had to intervene in the area of childcare. However, such intervention has remained limited. In 2000, a requirement for early childcare qualification was introduced. In 2005, the government established financial structures designed to encourage the employment of qualified staff in order to boost quality. In 2007, a scheme was introduced to provide 20 hours per week free in qualified teacher-led childcare services for three and four year olds with an aim to increase both the quality and affordability of childcare. However, privately provided childcare remains low in terms of quality and is particularly expensive, thus pricing out a large number of women (especially Māori and Pasifika women). Kesting and Fargher argue that the comparatively low female labour-force participation rate of mothers with dependent children in New Zealand can be explained at least in part by how childcare is organised. ${ }^{67}$ Watane and Gibson note that labour-force survey evidence shows that the barriers to training that are felt with relatively greatest frequency by Māori and Pasifika but also by others in precarious employment relate to family circumstances and access to childcare. ${ }^{68}$

\section{Other Developments}

The Clark government established the role of EEO Commissioner, the Human Rights Amendment Act and extended new grounds of discrimination to the public sector as well as providing a revised complaints resolution process. The EEO provisions found in the State Sector were also extended to the wider public sector through the Crown Entities Act. Another development was the establishment of a Tripartite Pay and Employment Equity Taskforce and they developed a five-year Pay and Employment Equity Plan of Action. The Pay and Employment Equity Unit was established in the then Department of Labour to support the implementation of the Government's Plan of Action on Pay and Employment Equity. The Tripartite Steering Group was established to lead and monitor the development and implementation of the Plan of Action.

67 Stefan Kesting, and Scott Fargher "The effect of early childhood education and care (ECE) costs on the labour force participation of parents in New Zealand” (2008) 33 NZJER 16.

68 Carolyn Watane, and John Gibson "Barriers to employment-related training in New Zealand: Differences across ethnic groups” (2001) 26 NZJIR 227. 


\section{Fifth National Government (2008-Present)}

In a move reminiscent of the earlier repeal of the Employment Equity Act 1990, one of the first actions of the Key government in 2009 was the discontinuations of pay investigations, the five-year Pay and Employment Equity Plan of Action and the disestablishment of Pay and Employment Equity Unit of the Department of Labour. ${ }^{69}$ Subsequently, there has been little further government movement on furthering equality for women in the workplace beyond minor tinkering. The changes to the Employment Relations Amendment Act 2014 came into force. It changes the process and right to request flexible working arrangements by opening the right to request to all employees, not just the ones with care commitments, and paid parental leave was extended from 14 to 16 and eventually to 18 weeks. Arguably, both measures look like a gain for employees, but in fact contribute to the further entrenchment of women into traditional caring roles. ${ }^{70}$ Indeed the use of flexible time by employees shows that men choose to work flexibly to do more work, while women choose to work flexibly to meet their care commitments. Thus, opening the right to request to all merely reinforces traditional structural gendered patterns. Providing longer parental leave might be welcomed by many, but without adequate compensation, only women can 'afford' to take such leave. Furthermore the systemic under-resourcing of the Human Rights Commission demonstrates a rather luke-warm commitment to furthering equality.

\section{The Present Day}

Forty years of workplace transformation revealed through the pages of the NZJIR and NZJER reveals a depressing degree of continuity. Concerns raised in the earlier years remain concerns today. In particular, the earliest issues of the NZJIR identified as problematic the fact that Māori and Pasifika women fare worse in the workplace than other women. This remains largely unchanged. Writing in 1994, Wilson commented that "women are still ghettoised in the workforce in occupations that are distinguished by their low skill and low pay. The trend of women into positions of authority is painfully slow." "71 Despite progress in education, this remains true today.

69 Prue Hyman "Pay equity and equal employment opportunity in New Zealand: Developments 2008/2010 and evaluation" (2011) 36 NZJIR 65.

70 Annick Masselot "Gender implications of the right to request flexible working arrangements: Raising pigs and children in New Zealand" (2015) 39 NZJER 59.

71 Margaret Wilson "Contractualism and the Employment Contracts Act 1991: Can they deliver equality for women?” (1994) 19 NZJIR 256 at 271. 


\section{Gender Pay Gap and Union Responsiveness to the Concerns of Women}

However, there is some light on the horizon. Although there has been little impetus from government in furthering equality, McGregor discusses how civil society has taken on a more active role. ${ }^{72}$ One thing that has changed from the 1970s is that it can no longer be said that unions are non-responsive to the needs of women and that they are male-dominated. Unions have led key campaigns and funded litigation to improve the working lives and financial situations of women. ${ }^{73}$ Most significantly, the Equal Pay Act of 1972, which had seemed ineffectual and largely moribund, formed the basis of the Bartlett $\nu$ TerraNova decision. ${ }^{74}$ This established that in female-dominated work the Equal Pay Act 1972 requires equal pay for work of equal value (pay equity), not simply the same pay for the same work as had been previously thought. In response to this, the government set up a Joint Working Group on Pay Equity in 2015, including employer, union and government representatives charged with developing and recommending pay equity principles. ${ }^{75}$

The Joint Working Group on Pay Equity Principles presented its report on 24 May $2016 .{ }^{76}$ Its recommendations covered both a process and criteria for the resolution of disputes. The recommendations largely build on existing good faith arrangements in the Employment Relations Act and on existing institutions and favour an approach rooted in early resolution. The government indicated on 24 November $2016^{77}$ that it accepted the recommendations although it intends to provide additional guidelines on the determination of suitable comparators. The Government also announced that it intended to introduce a Bill in 2017 which would make the necessary changes to the Equal Pay Act 1972 and the Employment Relations Act 2000 needed to implement the changes. At the time of writing, the Bill had just been introduced into Parliament following a period of public consultation..$^{78}$

72 Judy McGregor "The human rights framework and equal pay for low paid female carers in New Zealand” (2013) 38 NZJIR 4.

73 See for example the "Treat her Right Campaign" <http://www.treatherright.co.nz/>.

74 Bartlett $\nu$ TerraNova [2014] NZCA 516.

75 See <www.ssc.govt.nz/pay-equity-working-group-terms-reference>.

76 See <http://www.ssc.govt.nz/sites/all/files/pay-equity-jwg-recommendations.pdf>.

77 See <https://www.beehive.govt.nz/release/govt-accepts-recommendations-pay-equity-0>.

78 Employment (Pay Equity and Equal Pay) Bill 2017, see <http://www.mbie.govt.nz/infoservices/employment-skills/legislation-reviews/exposure-draft-employment-pay-equityand-equal-pay-bill>. 


\section{The Failure of Equal Employment Opportunities (EEO) and the Declining Number of Women in Senior Positions}

Although it is arguable women today have more likelihood of ascending to senior roles than they would have had in the 1970s, the number of women in senior positions remains low. Shamefully the number of women in senior positions has fallen under the Key government and the gender pay gap in government departments is not only broader in some State sectors than in the private sectors, it also has increased..$^{79}$ It seems that women's progress has not only stalled, but that New Zealand women are going backwards in terms of equality.

In the 1990s, as discussed above, the view was formed that EEO were best dealt with under a voluntarist regime. Apart from the requirements not to discriminate (which require an individual to raise a complaint), ${ }^{80}$ private sector organisations have no obligations, other than those they may voluntarily choose to assume to ensure EEO. They are not required to disclose any information regarding gender equity or equal employment opportunities.

There are some requirements around EEO in the state sector who must develop and implement EEO policies specifically targeted at women (as well as Māori, ethnic minorities and people with disabilities). Edgar suggests that this obligation has produced some measure of success by increasing the employment opportunities for target group members. ${ }^{81}$ Nonetheless, after all these years of EEO in the state sector, women are still unequal here with a recently reported shocking pay gap of 37 per cent. ${ }^{82}$

It seems the voluntarist approach is not working and perhaps it is time for more stringent measures. Mandatory reporting on gender outcomes for both the public and the private sector is one possibility. Brooks, Fenwick and Walker emphasise the importance of monitoring and evaluating progress rather than relying on measures such as the presence of EEO policies. ${ }^{83} \mathrm{~A}$ well-funded regulatory body to oversee this with the power to impose significant penalties on those non-compliant with reporting or found to be acting in ways that are

79 See <http://www.radionz.co.nz/news/national/294770/no-progress-on-gender-pay-gapprofessor>; and New Zealand Government Human Resource Capability Survey: In the New Zealand State Sector <http://www.ssc.govt.nz/sites/all/files/hrc-survey-2015_0.pdf>.

80 For a discussion on the limitations on relying on individually driven complaints to effect systemic change, see Amanda Reilly "Equality and family responsibilities: A critical evaluation of New Zealand law” (2012) 37 NZJER 161.

81 Fiona Edgar "Equal Employment Opportunity: Outcomes in the New Zealand Public Service" (2001) 26 NZJIR 217.

82 New Zealand Government "Human Resource Capability Survey: In the New Zealand State Sector” (2015) <http://www.ssc.govt.nz/sites/all/files/hrc-survey-2015_0.pdf>.

83 Ian Brooks, Graham Fenwick and Bernard Walker "The effect of changing perceptions of EEO on the appointment of women to management and supervisory positions in a public sector organisation” (2003) 28 NZJIR 23. 
discriminatory (such as in Australia) would also be desirable. Alternatively, mandatory measures such as quotas for women in senior roles have been proven to work in some countries where they are part of a holistic approach to gender equality. ${ }^{84}$ Unfortunately, New Zealand has not shown such a clear, holistic commitment to gender equality and, maybe more importantly, the public has generally been resistant to the introduction of mandatory measures like quotas. ${ }^{85}$ The 2012 HRC Census of Women's Participation observes that: ${ }^{86}$

Quotas appear to cut across one of the nation's most cherished myths, that we are a country where a "fair go" rules, both in aspiration and in practice. Successive administrations have denied any interest in debate about quotas in the belief that it would evoke negative political and business reactions and a "nanny state" backlash.

\section{Work and Family Mechanisms are Still Unsatisfactory}

In the 1970s there was a total absence of work-family reconciliation mechanisms. The first maternity leave provisions did not come into effect till 1981 and paid leave was only introduced in 2002, but take-up remains painfully low. The range of mechanisms supporting work-life balance is broad and relatively well articulated. However, it remains weak overall in comparison to other postindustrial countries, with low penalties for breaches and difficult access to justice for many in vulnerable positions. Moreover, although the work-life balance legal framework is drafted as gender neutral, it heavily impacts on women who continue to be seen as primary carers. For instance, the lack of adequate paid leave combined with the gender pay gap does not encourage fathers to be involved in childrearing nor a better sharing of unpaid domestic tasks. The amendments to the right to request flexible working arrangements (which extended the right to request for all workers) effectively treated the concept of care as irrelevant. Care giving, far from being considered a necessity, is treated as a lifestyle choice akin to gardening or golf playing. Arguably, a state-owned universal childcare model should be considered urgently, given the need to address the poor employment outcomes of Māori and Pasifika women. The emphasis on a business case and productivity arguments, as well as the failure to value care underpinning these mechanisms in New Zealand, is fundamentally flawed and counterproductive to any attempt to secure gender equality. Finally, there is a gap between the letter

84 Annick Masselot, and Timothy Brand "Diversity, quotas and compromise in the boardroom: Can New Zealand adopt a legislation to tackle gender imbalance in economic decision making?” (2015) 26 NZJULR 1.

85 Prue Hyman "Pay equity and Equal Employment Opportunity in New Zealand: Developments 2006/2008 and evaluation” (2008) 33 NZJER 1.

86 Judy McGregor "New Zealand Census of Women's Participation 2012” (2012) <www.hrc. co.nz>. 
of the law and its application. The lack of strong enforcement gives the message that gender equality and work-family reconciliation are issues for women only and, as such, are not serious issues in themselves.

\section{Sexual Harassment}

The poor record of employment institutions in dealing with sexual harassment has been raised in the pages of the NZJER over the years. ${ }^{87}$ Whether sexual harassment is being satisfactorily dealt with by New Zealand law remains an unanswered question. In one controversial Employment Relations Authority Decision, ${ }^{88}$ the view was expressed that a "fun slap" to the bottom can be seen in context as acceptable in the workplace. The high-profile Roger Sutton incident, ${ }^{89}$ and the Prime Minister repeatedly pulling a waitress's hair ${ }^{90}$ suggest some unacceptable attitudes towards sexual harassment are still prevalent and this may be seen as reflective of New Zealand's high domestic violence rates. ${ }^{91}$ Conversely, though the recent case where a sex worker was able to succeed against her employer for sexual harassment in the Human Rights Commission jurisdiction demonstrates the presence of more enlightened attitudes to sexual harassment..$^{92}$

The different approaches between jurisdiction is also apparent in the variance in the awards for humiliation, loss of dignity and injury to feeling in the Employment Relations Authority and the Human Rights Review Tribunals, with

87 Colin Hicks "Does the sexual harassment procedure work?” (1988) 13 NZJIR 291; William Davis A Feminist Perspective on Sexual harassment in Employment Law in New Zealand Monograph (New Zealand Institute of Industrial Relation Research, Wellington, 1994); Julie Debono "Sexual Harassment in Employment: An Examination of Decisions Looking for Evidence of a Sexist Jurisprudence" (2001) 26 NZJIR 329.

88 The Authority stated that "While inappropriate and which should not be repeated by $\mathrm{Mr}$ Sanson, [it] must be seen in context ... It was a one-off slap which I accept was a 'fun slap"”. Ms Newman was not only unsuccessful in her allegation of sexual harassment but was ordered to pay \$5,000.00 damages: Newman $\nu$ Taxi Lease Ltd t/a The Plant Place [2014] NZERA 481 and [2014] NZERA 525. The determination was challenged but settled before a hearing.

89 <http://www.stuff.co.nz/national/politics/63891913/roger-sutton-and-his-dramaticdownfall $>$.

90 <http://www.stuff.co.nz/national/68235578/John-Key-Ponytail-pull-not-sexist>.

91 Family Violence Death Review Committee Fourth Annual Report: January 2013 to December 2013 (Health Quality and Safety Commission, Wellington, 2014) <http://www.hqsc.govt. nz/our-programmes/mrc/fvdrc/publications-and-resources/publication/1600/>; Statistics New Zealand "New Zealand Police recorded crime and apprehension tables" (2015) <http:// nzdotstat.stats.govt.nz/wbos/Index.aspx?DataSetCode=TABLECODE7407>; See also the debacle over the Roast Busters, <http://www.stuff.co.nz/national/crime/10674764/RoastBusters-case-No-charges-to-be-laid>.

92 DML $\nu$ Montgomery [2014] NZHRRT 6. 
much higher awards being made in $\mathrm{HRRT}^{93}$ compared to the Authority. ${ }^{94}$ It may be this is an area where further improvement is possible.

\section{Conclusion}

Although New Zealand women have come a long way since the 1970s, women are still unequal in the workplace and they will not be equal, in terms of parity with men in the labour market, until adequate provisions are adopted with a view to providing the following:

(i) A pay equity system must be put in place to guarantee women equal pay for doing the same work and female-dominated professions need to be revalued so they receive better pay. Although it must be viewed as positive that subsequent to Bartlett $\nu$ Terranova all parties concerned are in agreement that women should not be paid less because their work is undervalued due to structural gender based differentiation, time alone will tell whether the Recommendations of the Joint Working Group on Pay Equity Principle are fit for the purpose of addressing this or, indeed, whether or in what form they will be implemented. Barriers to women entering male-dominated fields must also be addressed;

(ii) Effective mechanisms must be put in place to prevent discrimination and to address gender bias (both conscious and unconscious). In particular, sexual harassment should not be tolerated in the workplace and equal employment opportunity policies should not be voluntary. Outcomes should be measured and transparent and failures to comply should be penalised. Quotas could be another interim possibility to get more women into senior roles; and

(iii) Suitable mechanisms must be put in place to ensure work and family can be managed and the unpaid work evenly distributed. Access to child care must be improved.

Transformations for women at work do not occur in a vacuum and changes in the wider environment also impact on women (as they do on men). Pike River was a particularly egregious outcome of systemic under-enforcement of New Zealand's occupational health and safety law. However, this theme of under-enforcement of the law pertaining to equalising women in the workplace has been recurrent in the NZJER ${ }^{95}$ and there is little sign of improvement, with cuts to the Human Rights Commission and general under-resourcing of the institutions charged with enforcement as well as the increasing cost linked to individual access to justice.

93 MacGregor v Craig [2016] NZHRRT 6.

94 However, see Judge Inglis's comments in Hall $\nu$ Dionex PTY Ltd [2015] NZEmpC 29 at 87.

95 Prue Hyman "Review Article: Women and Pay" (1981) 6 NZJIR 79. 
Not all transformations in the workplace are positive. Unions are associated with better working conditions for women, but the decline of unions, the growing precariousness of work, the emergence of new ways of working and the decline of the standard employment contract all may operate to undermine ongoing further improvement in women's working lives. It may be that the future evolution of work will require new ways of thinking about work and an emphasis, as feminists have continuously called for, on valuing care work. ${ }^{96}$

As noted by McGregor, "women's progress in closing the gender pay gap in New Zealand at a governmental level is marked by the ebbs and flows of political will". ${ }^{97}$ Prue Hyman further explains that "since the 1980s Labour led governments have been somewhat more proactive in pursuing measures to further women's equality but both are nervous of any major interventions in the market". ${ }^{98}$ It is quite apparent that equal employment policies are not a priority in the current government's eyes, as is evidenced by the lack of progress and the continuing pay gap in the public sector. Coming up to an election year in 2017, if there is a change to a Labour-led government, perhaps there is hope that the current environment of backsliding and complacency towards women's inequality will change. This remains to be seen.

96 Amanda Reilly “Time, Work, and Law: A New Zealand perspective” (2012) 37 NZJER 152.

97 Judy McGregor "The human rights framework and equal pay for low paid female carers in New Zealand” (2013) 38 NZJIR 4.

98 Prue Hyman "Pay Equity and Equal Employment Opportunity in New Zealand: Developments 2008/2010 and Evaluation” (2011) 36 NZJER 65 at 66. 